\title{
Collaborative research between education and medical on study of early childhood neuroscience
}

\author{
Jumiatmoko \\ Faculty of Education Science, Universitas Sebelas Maret, Indonesia \\ E-mail: jumiatmoko1391@gmail.com
}

\author{
Article History \\ Submitted: April 5, 2020 \\ Accepted: May 12, 2020 \\ Published: June 29, 2020 \\ DOI: $10.26555 /$ jecce.v3i1.1671
}

\begin{abstract}
Student experiences information process causing particular behaviors while studying. Neuroscience is a study to understand behavior and mental process based on brain activity. In Indonesian, collaborative study between education and medicine on preschool-aged children's neuroscience is still scarce. In fact that using this collaboration, some elements related to student's behavior and information process can be seen. This paper spells out potential collaborative studies on neuroscience of preschool-aged children. This study is categorized into qualitative descriptive research. The data were collected through an indepth interview with the head of education and research section of UNS Hospital and document study. The result of the study found a number of potential collaborative studies between UNS Hospital and ECE department of UNS, namely: 1) Assessing level of stress using Bioneurofeedback; 2) Assessing Learning comfort using Electroencephalograph; 3) Assessing Interest and Aptitude using Electroencephalograph; and 4) Therapy on Gadget Addiction using Bio-neurofeedback. Those findings can be used as a basic for further research about neuroscience in early childhood.
\end{abstract}

Keywords : collaborative research, neuroscience, early childhood

\section{Abstrak}

Siswa mengalami pemrosesan informasi yang menyebabkan perilakuperilaku tertentu saat proses belajar. Neuroscience merupakan bidang ilmu untuk memahami perilaku serta proses mental seseorang berdasarkan kinerja otak. Kolaborasi penelitian yang melibatkan bidang pendidikan dan kedokteran pada kajian Neurosains anak usia dini masihjarang dilaksanakan di Indonesia. Padahal dengan menggunakan kolaborasi ini potensi yang berkaitan dengan perilaku maupun pemrosesan informasi siswa dalam belajar dapat dilihat. Penelitian ini memaparkan potensi-potensi kolaborasi penelitian Neurosains pada anak usia dini. Penelitian ini menggunakan metode Kualitatif Deskriptif. Data penelitian diperoleh dari wawancara mendalam dengan kepala seksi pendidikan dan penelitian RS UNS dan studi dokumen. Hasil penelitian ini memberikan peluang kolaborasi dengan prodi PG-PAUD UNS untuk melaksanakan penelitian dalam beberapa bentuk: 1) Pengujian Tingkat Stres menggunakan Bio-neurofeedback Equipment; 2) Pengujian Kenyamanan Belajar menggunakan Electroencephalograph tools; 3) Pengujian kecenderungan minat dan bakat menggunakan Electroencephalograph tools; dan 4) Terapi pemulihan ketergantungan gawai menggunakan Bio-neurofeedback Equipment. Hasil tersebut dapat digunakan sebagai dasar bagi penelitian selanjutnya yang menggunakan pendekatan neurosains.

Kata Kunci : penelitian kolaboratif, neurosains, paud 


\section{INTRODUCTION}

Opportunities and access to participate in education encourage the growth of the number of private early childhood education institutions. Statistical data on 2017/2018 Early Childhood Education (ECE) Institution published by the Ministry of Education and Culture's Center for Data and Statistics of Education showed that there were 87,726 (96.31\%) private ECE institutions and 3,363 (3.69\%) public ECE institutions. In Central Java Province, there are 14,166 ECE institutions (private $=13.963$; public $=153$ ), the second-largest after Yogyakarta Province . More than four million preschool-aged children attend private ECE institutions. The majority of parents believe that private ECE institutions offer a more variative, interesting curriculum with better quality than public ECE institutions do (Tim CNN Indonesia, 2019).

Good quality ECE programs can prepare children with better readiness to attend schools (Ansari \& Winsler, 2016). Every ECE program held by the community possesses certain purposes and expectations regarding the children's development. Some programs are international curriculum-based, such as Cambridge Curriculum, Montessori, Head Start, ICT programs, Quran Hafiz program, or forest school, among other programs.

An ideal learning program for preschool-aged children should be aimed to develop a robust learning foundation (Hanly et al., 2019) because this period greatly affects their learning development in their life (Slot et al., 2015). Learning stimulus given to preschool-aged children may shape their brain architecture, which functions as their learning power.

Recent studies have shown a clear sign that every learning program for preschool-aged children should be able to prevent them from possibilities of stress. Every learning program for preschool-aged children potentially results in toxic stress, a type of stress that hinders the optimization of the development of preschool-aged children's brain architecture.

This condition leads to significant difficulties for preschool-aged children to optimize their brain development, even when they are in a safe place, such as school (Center on the Developing Child at Havard University, 2011). National Scientific Council on the Developing Child explains that adequate understanding of preschool-aged children's stress, particularly caused by various learning programs, may help parents and teachers to determine preventive strategies and improvement interventions toward the programs. 
Every type of learning program held by ECE institutions should be able to guarantee learning comfort. After attending an ECE program, a child can conclude whether or not a school is a comfortable place for learning (Kostelnik et al., 2017). The use of brain testing instruments can help to identify learning comfort by viewing brainwaves that dominates during the learning phases. For instance, Alpha Zone, one of the brainwaves with a frequency of 7-13 Hz. This condition is the best (comfortable) phase for a child to learn (Chatib, 2011). A comfortable, stress-free learning activity, according to Harvard University's Center on the Developing Child, serves as a robust foundation to attain school success, economic productivity, and be a responsible citizen (National Scientific Council On The Developing Child, 2014). To date, some methods are used to examine the effect of learning program on preschool-aged children's development, such as a checklist, anecdotal note, and results of work (Suminah et al., 2018). Teachers can apply these methods through observation. In examining the children's development, teachers employ physical aspects of development. However, the children's brain development and the process cannot be examined comprehensively through physical observation. Such a physical observation also cannot convincingly explain signs of toxic stress and learning comfort that affect children's brain development.

Therefore, based on the condition stated earlier, it is interesting to employ other test methods that are capable of explaining the direct effect of the learning program on preschoolaged children's brain working process. The present study serves as a preliminary study that analyzes potential collaborative research between Sebelas Maret University's (UNS) ECE department and UNS Hospital. UNS hospital, as a medical education hospital, provides a range of opportunities to conduct medical analysis-based research on preschool-aged children's brain development. Instruments for testing the brain's working process such as Electroencephalography (EEG) in UNS Hospital provide opportunities to test preschool-aged children's development on a medical basis. Many developed countries have conducted brain working process analyses to examine the effects of learning processes on learners. The effects of learning processes (both stress and comfort) can be examined using EEG and BioNeurofeedback (Brouwer et al., 2011)

Besides, in the Indonesian context, collaborative studies on Neuroscience are still scarce. Majority of neuroscience studies in Indonesian education context rely on document studies ( $R$. 
L. Ambardini, 2009; Rustiana, 2011). Howard-Jones prove that neuroscience study is able to better explain changes in behavior and brain working process affected by learning activities (Bowers, 2016).

\section{METHOD}

This study applied qualitative approach with descriptive method. Qualitative approach has many methods, its primary characteristics are interpretative and natural (Putra \& Dwilestari, 2016). This method is suitable for gaining an in-depth understanding of the participant's natural context in order to interpret the meaning of phenomena. This study describes potential collaborative studies between UNS'S ECE department and UNS Hospital in examining preschool-aged children's level of stress, learning comfort, interest and aptitude detection, and gadget addiction.

The data of the study were collected through an in-depth interview with the head of Education and Research Section of UNS Hospital (Sugiyono, 2013). Literature study on secondary data was conducted to enrich best practice studies on neuroscience by analyzing neuroscience articles like those on the Basic and Clinical Neuroscience Journal.

\section{RESULT AND DISCUSSION}

UNS Hospital is UNS' technical unit force to support the rector's work in healthcare field. It functions as a place of integrated education, research, and healthcare in the field of medical education and/or dentistry, continuing education, and other medical education. This hospital is located in Jalan Ahmad Yani 200, Makamhaji Kartasura. It obtains its operating license in 2016. Its main duty is to carry out Medical Education and Research. It carries out educational activities for young doctors and studies in medical field. The researcher conducted an in-depth interview with the Head of Education and Research Section of UNS Hospital. The interview was conducted in MERC UNS building in December 2019 and January 2020.

Based on the interview, some potential collaborative studies involving preschool-aged children were found, both short-term and longterm. These are: 
1) Assessing Preschool-aged Children's stress level

Children potentially face stress in various learning programs held by the school. Recently, people around the globe put great pressure on academic tasks for preschoolaged children. This phenomenon arises because people believe that it is better to make children academically intelligent earlier. This condition is called by education experts 'erosion' of childhood. Many doctors report a higher number of children's visits due to illness and stress (Al-Yateem et al., 2015).

UNS Hospital provides opportunities for collaborative research to examine preschool-aged children's level of stress. In order to examine preschool-aged children's level of stress, Bio-Neurofeedback equipment is used. Using this method, it is expected to find out various programs that stimulate preschool-aged children's development and their effects on the children's level of stress.

Not all stresses that occur during childhood can be detected through physical observation. Assessment using Bio-neurofeedback equipment may exhibit a child's level of stress in a better manner, compared to physical observation. This assessment generates data in the form of heartbeat, skin conductance, and muscle tension. Assessing stress, particularly toxic stress, in childhood is pivotal to prevent numerous potential negative effects. By understanding preschool-aged children's level of stress using BioNeurofeedback, a number of matters that harms preschool-aged children's brain development can be prevented, such as: a) Damage in brain tissue. Even in some cases, toxic stress leads to smaller brain development; b) It causes brain's low level of stresscoping ability. Such a condition makes a child reactive to various stress-triggering condition; c) High level of stress triggers secretion of cortisol and also leads to immunity issues. In such condition, children usually are prone to various infections and chronic diseases. d) High secretion of cortisol adversely affects the performance of hippocampus, a part of the brain that functions for learning and storing memory.

Collaborative studies to assess children's level of stress may focus on those attending learning programs in institutions with various special programs, such as international curriculum, religious programs, IT programs, forest school basis, and other programs. Assessing preschool-aged children's level of stress in various learning programs may result 
in comparison of level of stress, as well as reflection for institutions to always improve the quality of their programs. In addition, publishing the result of such a study can bring greater benefits for community. It can be used as a consideration in understanding the dynamics of relationship between ECE program and the children's level of stress.

2) Assessing learning comfort

Programs for stimulating preschool-aged children should prioritize children's comfort. Children who feel comfortable and safe will find it easier to participate in learning, whereas those who are anxious, angry, or fearful will find it difficult to participate in the learning program. Children's feelings of safety and comfort stem from warm accompaniment from adults who are close to them (Guay et al., 2019). Their comfort during the learning process can also stem from the learning approach when implementing the program. Learning comfort is negatively associated with learning stress. The higher the individual's learning comfort, the lower his/her learning stress, and vice versa. It is necessary to conduct a clinical test on learning comfort to support the result of physical observations.

The Head of Research and Education Section of UNS Hospital stated that learning comfort can be measured using EEG. In a collaborative study, it is measured in two main steps, namely 1) test on brainwaves distribution using EEG, which is carried out by UNS Hospital, and 2) the analysis and confirmation of EEG test result using a clinical interview with the participants of the study, which is conducted by UNS's ECE department.

The result of the first step will exhibit participants' brainwaves when given a certain stimulus (i.e., learning programs attended by preschool-aged children). This test exhibits an image of brainwaves distribution when learning stimulus is given. Every brainwave (Alpha, Beta, Theta, and Gamma) represents the level of learning comfort experienced by preschool-aged children. The second step (i.e., clinical interview) is carried out to gain an in-depth understanding of clinical facts (Ginsburg, 2014).

Contextually, teachers and parents need to understand children's comfort when participating in a learning program. Thus, they can prevent and improve programs that empirically fail to provide children with comfort. It is important to measure the quality of 
preschool-aged children's learning activity so that the measurement could be more student-centered.

3) Assessing Interest and Aptitude

Indonesia Career Center Network (ICCN), in 2017, reported important data regarding university students' interest in their study program. It reported that $87 \%$ of students attended study program that does not fit their interest (Makmun, 2017). This is, of course, not a simple issue. This report means that most Indonesian human resources will possess a low level of comfort when entering the world of work. Besides, many university graduates will work in a field that does not fit their study program. The worst possible impact of this condition is unemployment due to frustration when choosing a career. This condition can be minimized when children know early about their interest and aptitude. Furthermore, learning programs can be carried out more effectively when it fits children's interest and aptitude.

Collaborative research on this variable may serve as one of the alternatives to find out children's interest and aptitude earlier. Current studies on brain functions exhibit the benefits of revealing children's learning modality. In this case, brainwaves can be used as a basis to determine children's leadership aptitude, business interest, and so forth. UNS Hospital's EEG tool can also be used to detect an individual's interest and aptitude.

The result of the EEG test is then confirmed by researchers from ECE department through clinical interviews or observations in order to obtain a comprehensive, physical, and non-physical description of certain interests and aptitude. The result of such a study can be used as a basis to understand children's interest and aptitude earlier.

This kind of study is a novelty in ECE research, especially in mapping preschool-aged children's interest and aptitude. This kind of study provides teachers and parents with opportunities to prepare programs that better suit children's interest and aptitude.

4) Therapy on Gadget Addiction

A high number of children's gadget use is now viewed as a global issue faced by many parents. New York Times reported that $72 \%$ of preschool-aged children have used gadgets, especially smartphones (Khairunnisa, 2016). The head of Education and Research Section of UNS Hospital stated that issues on preschool-aged children's gadget addiction 
can be treated using Bio-Neurofeedback Equipment. This therapy will require collaboration between the therapist, ECE teachers, and parents to alleviate children's gadget addiction. In general, Bio-neurofeedback is carried out in a certain protocol to establish self-control in children's brains.

The success of activating self-control in children's brains should be followed up by teachers' and parents' consistent guidance.on children. Treatment using the same instrument has shown successes in handling children's brain dysfunctions, such as hyperactivity, epilepsy, insomnia, drug addiction, learning disabilities, dyslexia, dyscalculia, autism, among other dysfunctions (Marzbani et al., 2016). Study in this field can promote a simultaneous collaboration between the ECE department and UNS hospital to solve issues faced by early-aged children in the digital era. Issues on children's gadget addiction have emerged as serious problems that cannot be solved without collaborations of many parties.

The present study reveals a number of potential collaborative studies that can be conducted by ECE Department and UNS Hospital as seen on table 1.

Table 1 Potential Collaborative Studies between ECE Department of UNS and UNS Hospital

Assessing preschool-aged children's level of stress using a range of variables (e.g., development stimulation, learning program, etc).

Assessing preschool-aged children's learning comfort using a range of variables (e.g., development stimulation, learning program, etc). Assessing preschool-aged children's Interest and Aptitude Therapy on Gadget Addiction for preschool-aged children
Bio-neurofeedback Equipment

EEG (Electroencephalography) tools

EEG (Electroencephalephalo-graphy) tools Bio-neurofeedback

These potential collaborative studies are expected to give contribution to ECE department and UNS Hospital. The main outputs of these studies will be used as materials for neuroscience in early childhood education by ECE Department. The teaching materials will be contextual in nature. Moreover, these collaborative studies may promote students' 
participation in conducting neuroscience studies in the field of preschool-aged children. they can also directly involve in various research processes.

For UNS Hospital, these collaborative studies can provide featured non-regular services. These non-regular services are tests on level of stress, learning comfort, child's interest and aptitude test, and therapy on various learning problems faced by children. Figure 1 shows the potential collaboration research that may conducted by UNS Hospital and Department of Early Childhood Education in the context of neuroscience.

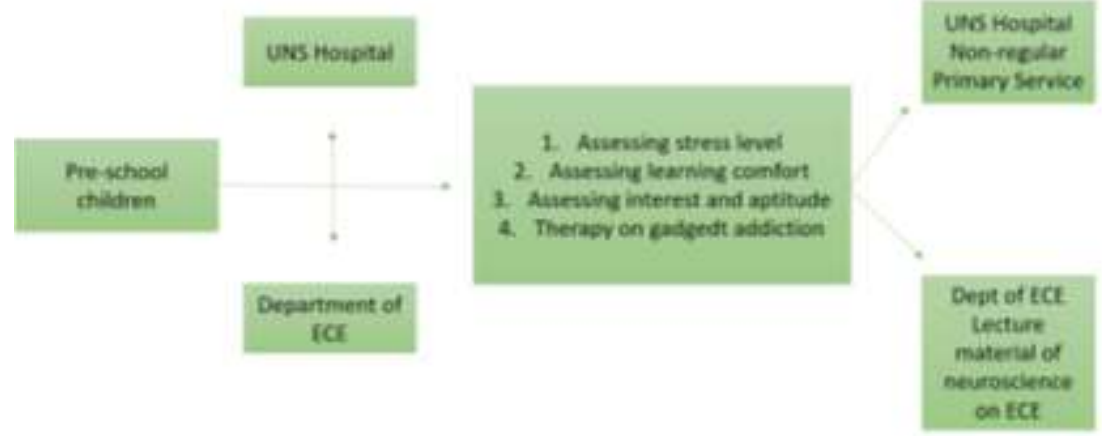

Figure 1. Collaborative Research between ECE Department and UNS Hospital

These collaborative studies can be carried out through some funding schemes provided by UNS. Every lecturer in a research group (RG) can submit proposals for funding through UNS's Intelligent Research and Innovation Service (IRIS) site. It is expected to gain research funds from Penelitian Unggulan UNS for two years.

\section{CONCLUSION}

The finding of the present study shows a number of potential collaborative studies for ECE Department and UNS Hospital in the field neuroscience of preschool-aged children's development. The collaborative studies are in the form of 1) Assessment of preschool-aged children's level of stress using Bio-neurofeedback; 2) Assessment of preschool-aged children's learning comfort using Electoenephalograph; 3) Assessment of preschool-aged children's interest and aptitude using Electroencephalograph, and 4) Therapy on preschool-aged children's gadget Addiction using Bio-neurofeedback. 
UNS Hospital's instruments and human resources allow us to conduct further collaborative studies on preschool-aged children's development. The results of these four collaborative studies can be used as neuroscience learning material in ECE and published as a practice of collaborative neuroscience study on preschool-aged children.

\section{REFERENCES}

Al-Yateem, N. S., Banni Issa, W., \& Rossiter, R. (2015). Childhood stress in healthcare settings: Awareness and suggested interventions. Issues in Comprehensive Pediatric Nursing, 38(2), 136-153. https://doi.org/10.3109/01460862.2015.1035465

Ambardini, R. L. (2009). Pendidikan jasmani dan prestasi akademik: Tinjauan neurosains. Jurnal Pendidikan Jasmani Indonesia, 6(1), 7. https://doi.org/10.21831/jpji.v6i1.432

Ansari, A., \& Winsler, A. (2016). Kindergarten readiness for low-income and ethnically diverse children attending publicly funded preschool programs in Miami. Early Childhood Research Quarterly, 37, 69-80. https://doi.org/10.1016/j.ecresq.2016.06.002

Bowers, J. S. (2016). Psychology, not educational neuroscience, is the way forward for improving educational outcomes for all children: Reply to Gabrieli (2016) and Howard-Jones et al. (2016). Psychological Review, 123(5), 628-635. https://doi.org/10.1037/rev0000043

Brouwer, A.-M., Neerincx, M. A., \& Kallen, V. (2011). EEG alpha asymmetry, heart rate variability and cortisol in response to virtual reality induced stress. Journal of Cyber Therapy and Rehabilitation, 4(1), 83-99.

Center on the Developing Child at Havard University. (2011). Building the Brain's "Air Traffic Control" System: How Early Experiences Shape the Development of Executive Function. Harvard University. http://developingchild.harvard.edu/index.php/ download_file//view/836/

Chatib, M. (2011). Gurunya Manusia. Kaifa.

Ginsburg, H. (2014). Menyelami Pikiran Anak: Wawancara Klinis dalam Penelitian dan Praktik Psikologi Anak (I). Pustaka Pelajar.

Guay, F., Stupnisky, R., Boivin, M., Japel, C., \& Dionne, G. (2019). Teachers' relatedness with students as a predictor of students' intrinsic motivation, self-concept, and reading achievement. Early Childhood Research Quarterly, 48, 215-225. https://doi.org/10.1016/j.ecresq.2019.03.005

Hanly, M., Edwards, B., Goldfeld, S., Craven, R. G., Mooney, J., Jorm, L., \& Falster, K. (2019). School starting age and child development in a state-wide, population-level cohort of children in their first year of school in New South Wales, Australia. Early Childhood Research Quarterly, 48, 325-340. https://doi.org/10.1016/j.ecresq.2019.01.008 
Khairunnisa, E. (2016). Tingkat kecanduan gadget pada anak mengkhawatirkan. CNN Indonesia. https://www.cnnindonesia.com/tv/20160603100101-403-135651/tingkat-kecanduangadget-pada-anak-mengkhawatirkan

Kostelnik, M. J., Soderman, A. K., \& Whiren, A. P. (2017). Kurikulum Pendidikan Anak Usia Dini Berbasis Perkembangan Anak (Terjemah). Kencana.

Makmun, M. (2017). 87\% Mahasiswa Indonesia Salah Jurusan. Berita Satu. https://www.beritasatu.com/mardiana-makmun/nasional/448668/87-mahasiswaindonesia-salah-jurusan

Marzbani, H., Marateb, H., \& Mansourian, M. (2016). Methodological note: Neurofeedback: A comprehensive review on system design, methodology and clinical applications. Basic and Clinical Neuroscience Journal, 7(2). https://doi.org/10.15412/J.BCN.03070208

National Scientific Council On The Developing Child. (2014). Stress Disrupts the Architecture of the Developing Brain. Harvard University.

Putra, N., \& Dwilestari, N. (2016). Penelitian Kualitatif PAUD (Pendidikan Anak Usia Dini) (4th ed.). PT Raja Grafindo Persada.

Rustiana, E. R. (2011). Efek psikologis dari pendidikan jasmani ditinjau dari teori neurosains dan teori kognitif sosial. Media Ilmu Keolahragaan Indonesia, 1(2), 4.

Slot, P. L., Leseman, P. P. M., Verhagen, J., \& Mulder, H. (2015). Associations between structural quality aspects and process quality in Dutch early childhood education and care settings. Early Childhood Research Quarterly, 33, 64-76. https://doi.org/10.1016/j.ecresq.2015.06.001

Sugiyono. (2013). Metode Penelitian Kuantitatif, Kualitatif, dan R\&D. Alfabeta.

Suminah, E., Siantayani, Y., Paramitha, D., Ritayanti, U., \& Nugraha, A. (2018). Pedoman Penilaian Pembelajaran Pendidikan Anak Usia Dini. Direktorat Pembinaan Pendidikan Anak Usia Dini DIrektorat Jenderal Pendidikan Anak Usia Dini dan Pendidikan Masyarakat Kementerian Pendidikan dan Kebudayaan.

Tim CNN Indonesia. (2019). Sekolah anak: Antara kebutuhan anak dan obsesi orang tua. CNN Indonesia. $\quad$ https://www.cnnindonesia.com/gaya-hidup/20191220192115-284458852/sekolah-anak-antara-kebutuhan-anak-dan-obsesi-orang-tua 